УДК 37.018.43:004:37.014.6 (436)

DOI https://doi.org/10.24919/2308-4863/34-4-36

\author{
Галина ОЛЕКСІВ, \\ orcid.org/0000-0002-8800-6217 \\ старший викладач кафедри іноземних мов \\ Національного університету «Львівська політехніка» \\ (Львів, Украӥна) halyna.d.oleksiv@lpnu.иа
}

Оксана ШИЙКА, orcid.org/0000-0002-0649-1205 кандидат педагогічних наук,

викладач

Львівського техніко-економічного коледжу Національного університету «Львівська політехніка»

(Львів, Україна) shyyka@ukr.net

\title{
РОЗРОБКА СТРАТЕГІЇ ТА РЕГУЛЮВАННЯ ЯКОСТІ ЕЛЕКТРОННОЇ ОСВІТИ В УНІВЕРСИТЕТАХ АВСТРIї
}

У статті розглянуто теоретичні засади стратегічного планування розвитку університетів. Виокремлено, зокрема, характерні ознаки формування стратегії університетів, проілюстровані конкретними прикладами. Акцентовано на особливостях стратегічного планування забезпечення якості університетської освіти в Австрії, виокремлено особливості регулювання якості електронної освіти.

Розглянуто особливості інтерпретаиії понять: електронне (e-learning), дистанційне (distance learning) $i$ змішане навчання (blended learning), окреслено масштаби й досвід використання відповідних технологій. Розглянуто побудову стратегічних планів двох провідних австрійських університетів - Університету ім. Карла Франца м. Іраи і Дунайського університету м. Кремс.

Зазначено, шзо стратегічне планування Університету ім. Карла Франца м. Граи визначає загальноуніверситетську місію, системи иілей університету й основні стратегії діяльності. Складовими частинами плану $є$ плани академічних підрозділів, розроблені відповідно до обраних напрямів, крім того, представлені кооперативні стратегічні проєкти їх співпрачі, вказані конкретні виконавці й терміни виконання.

Виокремлено особливості стратегічного планування Дунайського університету м. Кремс, зокрема посилення спеціалізації університету в галузях навчання та наукових досліджень; підвищення ефективності наукових досліджень; подальше зміџнення та розбудова позииій університету як передового європейського закладу

Зазначено, щз електронне навчання є невіддільним елементом діяльності обидвох університетів.

Виокремлені особливості творчого поєднання сучасних інформаційно-комунікачійних і педагогічних технологій, завдяки яким австрійські університети забезпечують якість освіти задля підвищення конкурентоздатності освітніх послуг на внутрішньому й міжнародному ринку.

Ключові слова: стратегічне планування, університет, Австрія, електронна освіта, якість університетської освіти, менеджмент якості. 


\section{Олексів Г., ШWийа О. Ровровка стратегіl та регукювання якості ..}

\section{Halyna OLEKSIV, \\ orcid.org/0000-0002-8800-6217 \\ Senior Lecturer at the Department of Foreign Languages \\ Lviv Polytechnic National University \\ (Lviv, Ukraine) halyna.d.oleksiv@lpnu.ua}

Oksana SHYYKA,

orcid.org/0000-0002-0649-1205

Candidate of Pedagogical Sciences,

Lecturer

Lviv Technical and Economic College

of the Lviv Polytechnic National University

(Lviv,Ukraine)shyyka@ukr.net

\section{DEVELOPMENT OF STRATEGY AND REGULATION OF ELECTRONIC EDUCATION QUALITY IN UNIVERSITIES OF AUSTRIA}

The theoretical foundations of strategic planning of university development have been reviewed in the article. The characteristic features of the formation of the strategy of universities, which are illustrated by specific examples, have been highlighted. Increased emphasis has been placed on the peculiarities of strategic planning which ensure the quality of university education in Austria. The peculiarities of regulating the quality of e-education have been highlighted.

Peculiarities of interpretation of such concepts as: e-learning, distance learning and blended learning have been pointed out. Standards and experience in appropriate technologies usage have been outlined. The development of strategic plans of two leading Austrian universities (University of Karl Franz in Graz and the University of the Danube in Krems) has been considered.

It has been highlighted that the strategic planning of Graz University of Karl Franz defines the general mission, goal systems and the main business strategies of the university. The components of the plan are the plans of academic units, developed according to the selected areas; besides, cooperative strategic projects of their cooperation are presented and specific executors and deadlines are specified.

The peculiarities of the strategic planning of the Danube University of Krems have been highlighted. In particular, the strengthening of the university's specialization in the fields of education and research, increasing the efficiency of scientific research, further strengthening and building of the position of the university as a leading European institution have been pointed out.

It has been noted that e-learning is an integral part of both universities.

The peculiarities of the creative combination of modern information, communication and pedagogical technologies, due to which Austrian universities ensure the quality of education in order to increase the competitiveness of educational services in the domestic and international market, have been highlighted.

Key words: strategic planning, university, Austria, e-education, quality of university education, quality management.

Постановка проблеми. В австрійському секторі вищої освіти елементи навчання, пов'язані 3 використанням мережі Інтернет, використовуються вже досить тривалий час. Масштаби й досвід використання технологій електронного (e-learning), дистанційного (distance learning) i змішаного навчання (blended learning) виражені по-різному, але в цілому характеризуються стрімким зростанням. На жаль, повного опису сучасного середовища електронного навчання у вищій освіті, яке, на перший погляд, видається досить гетерогенним, дотепер ще не проведено. Подібне узагальнення наявних стратегій, ресурсів, способів організації та відповідного досвіду дасть основу, яка матиме важливе значення для прийняття відповідних освітніх та економічних заходів.

Аналіз досліджень. Стосовно визначень основних понять, то досить часто вживаним i таким, що викликає найбільший інтерес у сучасних реаліях, $є$ «стратегія електронного навчання (e-leaming). Так, термін «стратегія електронної освіти» в дослідженні авторів D. Euler i S. Seufert трактується як систематичний доступ до освітньої послуги, а також іiї багатовимірний аспект, під час якого в центрі уваги знаходиться дидактична й технологічна складова частина (Euler, Seufert, 2005).

Терміни «електронна освіта» й «змішана освіта» в цьому ж дослідженні інтерпретуються таким чином: «електронна освіта - всі види навчання та викладання, що реалізуються за умови застосування інформаційних i комунікаційних технологій як у контексті обов' язкових занять, так i «віддаленого» навчання, а також комбінації обидвох («змішане навчання»)» (Euler, Seufert, 2005).

Окрім того, різноманітні особливості впровадження електронної освіти в практичну діяльність закладів вищої освіти України описані в роботах вітчизняних авторів, зокрема О. О. Андреєва, К. Л. Бугайчука, Т. М. Кронівець та низки інших (Кронівець, 2013: 135), (Андреєв, 2013: 132). 
Мета статті. Отже, загальною метою нашого дослідження буде спроба дослідження процесу розробки стратегії та регулювання якості електронного навчання в закладах вищої освіти Австрії на основі законодавства й документів, що є у вільному доступі (плани розвитку університетів).

Виклад основного матеріалу. Якщо брати до уваги систему менеджменту якості освітньої установи університетського рівня, то іiі основними завданнями $є$ підтримка й подальше удосконалення iĭ основних функцій - навчання та наукових досліджень. Водночас особлива увага звертається на стратегічну спрямованість забезпечення якості та іiі місце в загальноуніверситетській системі управління. Процес управління якістю освіти $є$ невіддільною частиною стратегічного планування діяльності університету. Він повинен базуватися на науково обгрунтованій стратегії розвитку університету й на соціально-економічних реаліях, що склалися на сучасному етапі на державному й міжнародному рівнях (Князев, 2005).

Стратегічне планування у сфері управління якістю вищої освіти можна схарактеризувати як процедуру створення та забезпечення стратегічного балансу між метою університету, його потенційними можливостями й імовірністю досягнення позитивних результатів на ринку освітніх послуг. Основу стратегічного плану має складати всебічний аналіз можливостей освітнього закладу 3 урахуванням змін у зовнішньому середовищі. На основі такого аналізу формується стратегія розвитку організації, визначаються цільові пріоритети. Стратегічне планування загалом спрямовується на адаптацію діяльності університету до мінливих умов зовнішнього середовища й на отримання вигод із нових можливостей (Князев, 2005).

Австрійські університети нині приймають, переглядають та оновлюють власні стратегічні плани. Зокрема, план розвитку Університету ім. Карла Франца м. Ірац на 2019-2024 роки містить елемент стратегічного планування, в основу якого покладено використання комплексного підходу, що визначає загальноуніверситетську місію, системи цілей університету й основні стратегії діяльності. Складовими частинами плану є плани академічних підрозділів, розроблені відповідно до обраних напрямів, крім того, представлені кооперативні стратегічні проєкти їхньої співпраці, вказані конкретні виконавці й терміни виконання (Entwicklungsplan 2019-2024: Die Karl-FranzensUniversität Graz, 2019).

Дунайський університет м. Кремс - один із найбільших європейських закладів, що спеціалізується на післядипломній освіті. Висока якість освіти тут досягається шляхом органічного поєднання сучасної практичної бази підготовки із сучасним науково-дослідним забезпеченням навчального процесу. Дунайський університет м. Кремс представив план розвитку на 2019-2024 роки, в тому числі декілька стратегічних питань, визначених на основі використання проблемного підходу. У вказаний період заплановані для розв'язання такі стратегічні проблеми, як: посилення спеціалізації університету в галузях навчання та наукових досліджень; підвищення ефективності наукових досліджень; подальше зміцнення та розбудова позицій університету як передового європейського закладу в галузі післядипломної освіти, представлення стратегій удосконалення якості й професійного розвитку кадрів, забезпечення надійних джерел фінансування університету в майбутньому. У плані розвитку намічено також відповідні шляхи подолання цих проблем (Entwicklungsplan der Universität für Weiterbildung Krems (Donau-Universität Krems), 2019).

Що стосується технології електронного навчання, то в освітній діяльності обидвох університетів вона $є$ невіддільним елементом, хоча в програмних документах особливості іiі застосування викладені небагатьма положеннями. Це пояснюється тим, що електронна освіта натепер набула значного поширення серед європейських закладів університетського рівня, і цей очевидний факт не потребує додаткової констатації. У стратегічному документі «План розвитку Університету ім. Карла Франца м. Грац на 2019-2024 рр.» міститься положення про «Розумний (інтелектуальний) університет» (“Smart University"). Така концепція реалізується завдяки «розумному поєднанню цифрових та аналогових технологій». Зазначається, що саме такий підхід $\epsilon$ баченням найближчого майбутнього в «наукових дослідженнях, викладанні й адмініструванні». Через систему управління навчанням студентам, зокрема, надається індивідуальний навчальний матеріал, а викладачам - можливості структурування його за темами й курсами, ефективної перевірки засвоєних знань та аналізу результатів навчання (Entwicklungsplan 2019-2024: Die KarlFranzens-Universität Graz, 2019).

3 метою адекватного реагування на надзвичайну ситуацію (пандемія COVID-19) Дунайський університет м. Кремс також декларує готовність до проведення всіх навчальних курсів в онлайн-форматі. Трактуючи таку ситуацію як виклик, в плані додаткової гнучкості навчального процесу з боку місця, часу й застосування нових, інноваційних форматів навчання універси- 
тет гарантує належну якість навчального процесу й повну відповідність обсягам у кредитах Європейської кредитної трансферної системи й кількості годин навчальних занять (Entwicklungsplan der Universität für Weiterbildung Krems (DonauUniversität Krems), 2019).

Надалі в програмних документах деталізуються стратегічні цілі управління якістю освіти університетів, які зводяться до рівня організаційної структури, розроблення плану їх реалізації та визначення конкретних інструментів їх досягнення. Тим самим визначення конкретних цілей у досягненні якісних показників базується на чіткій структурі, відповідальності виконавців, постійному моніторингу й оцінюванні, а також взаємозв'язках на всіх рівнях.

Зокрема, в «Стратегії розвитку університету ім. Карла Франца м. Грац» зазначено, що, визначаючи стратегічні цілі управління, університет, безперечно, керується і засадами менеджменту якості. Йдеться про запровадження загальноуніверситетської культури якості, яка є складовою частиною інтелектуального капіталу навчального закладу, відповідні зміни в його стратегії, оптимізацію всіх управлінських процесів, поліпшення зовнішніх комунікацій, розробку системи критеріїв оцінки рівня якості роботи різноманітних підрозділів та окремих посадових осіб (Entwicklungsplan 2019-2024: Die Karl-Franzens-Universität Graz, 2019).

Саме тут слід зазначити, що система менеджменту Університету м. Грац функціонує із застосуванням наукових принципів, різноманітності методів, креативності й перебуває в органічній єдності із загальноуніверситетською системою менеджменту.

Зокрема, стратегічна мета «Подальший розвиток системи менеджменту якості» конкретизується так:

1) оптимізація вже наявних інструментів досягнення якості;

2) інтенсивний обмін інформацією та підвищення чіткості цілей, заходів і конкретних показників;

3) активізація участі співробітників у розвитку якості (структури якості);

4) поліпшення взаємозв'язку між окремими інструментами забезпечення якості;

5) застосування в рамках аудиту якості запланованих заходів.

Щоб досягти запланованої мети, Університет м. Грац заздалегідь планує систему відповідних заходів. Зокрема, у 2013 році система менеджменту якості пройшла заплановану аудиторську перевірку фінською агенцією якості й отримала відповідний сертифікат, чинний до кінця 2020 року (Entwicklungsplan 2019-2024: Die KarlFranzens-Universität Graz, 2019).

Що стосується стратегічних цілей управління якістю Дунайського університету м. Кремс, то вони сформульовані кількома положеннями й полягають у такому: подальший розвиток і розбудова внутрішньої системи управління якістю, відповідних інструментів іiї забезпечення та розвитку. Їхня реалізація здійснюється через внутрішню систему оцінювання різноманітних аспектів діяльності університету, а також зовнішні заходи забезпечення якості, передбачені законодавством (Entwicklungsplan der Universität für Weiterbildung Krems (Donau-Universität Krems), 2019).

3 оцінкою (аналізом) наявної ситуації та встановленням стратегічних цілей управління якістю університету пов'язаний вибір концепції забезпечення належного рівня якості його функціонування.

Зокрема, в задекларованій концепції забезпечення якості освіти Університету ім. Карла Франца м. Грац визначено, що високі успіхи в навчанні й дослідженнях є першочерговою метою університету. Саме задля цього функціонує система забезпечення якості університету, яка $є$ частиною загальноуніверситетської системи менеджменту. Система охоплює множину всіх робіт, які забезпечують досягнення певного рівня якості навчання в університеті й спрямовані на досягнення стратегічної мети університету в контексті забезпечення якості навчання та наукових досліджень (Entwicklungsplan 2019-2024: Die KarlFranzens-Universität Graz, 2019).

У вказаному документі зазначено, що згідно 3 Болонською декларацією та Стандартами й рекомендаціями для гарантії якості в Європейському просторі вищої освіти основна відповідальність за якість та її оцінювання покладена на заклади освіти університетського рівня в рамках їхньої автономії. Зобов'язання забезпечувати якість освіти в державних університетах сформульоване в Університетському законі, прийнятому у 2002 році. Згідно з його $\S 14$, саме на університетах лежить відповідальність за побудову й функціонування системи менеджменту. Зазначені положення було підкріплено нововведеннями, задекларованими в Законі про забезпечення якості освіти у ВНЗ та австрійською агенцією із забезпечення якості й акредитації Австрії (нім. Bundesgesetz über die externe Qualitätssicherung im Hochschulwesen und die Agentur für Qualitätssicherung und Akkreditierung Austria, Hochschul-Qualitätssicherungsgesetz, HS-QSG) (далі - Закон про 
забезпечення якості освіти у ВНЗ). Вони полягали в тому, що сертифікація системи менеджменту університету здійснюється шляхом проведення аудиту п'яти визначених сфер його діяльності (Entwicklungsplan 2019-2024: Die Karl-FranzensUniversität Graz, 2019).

У концепції забезпечення якості освіти Університету ім. Карла Франца м. Грац зазначено також, що система менеджменту якості університету нині орієнтується на такі сфери діяльності університету, як: дослідження, навчання та викладання, професійне зростання кадрів, наукові дослідження, управлінська, фінансова й соціально-культурна інфраструктура університету (Entwicklungsplan 2019-2024: Die Karl-FranzensUniversität Graz, 2019).

Особливості застосування конкретних інструментів менеджменту в зазначених сферах конкретизовані в такий спосіб:

- в управлінській площині об'єктами впливу є система стратегічних цілей діяльності університету, процеси їх розробки й план досягнення;

- у площині навчання закладені максимальна підтримка й супровід студентів у навчальному процесі. Нові ідеї та концепції допомагають удосконаленню та подальшому розвитку якості викладання. Університет, отже, бере тим самим на себе відповідальність за якість освіти власних випускників і за їх конкурентоспроможність на ринку праці. Конкретними інструментами впливу тут $\epsilon$ вдосконалення змістового наповнення навчального процесу, а також перевірка й удосконалення організації навчання та викладання;

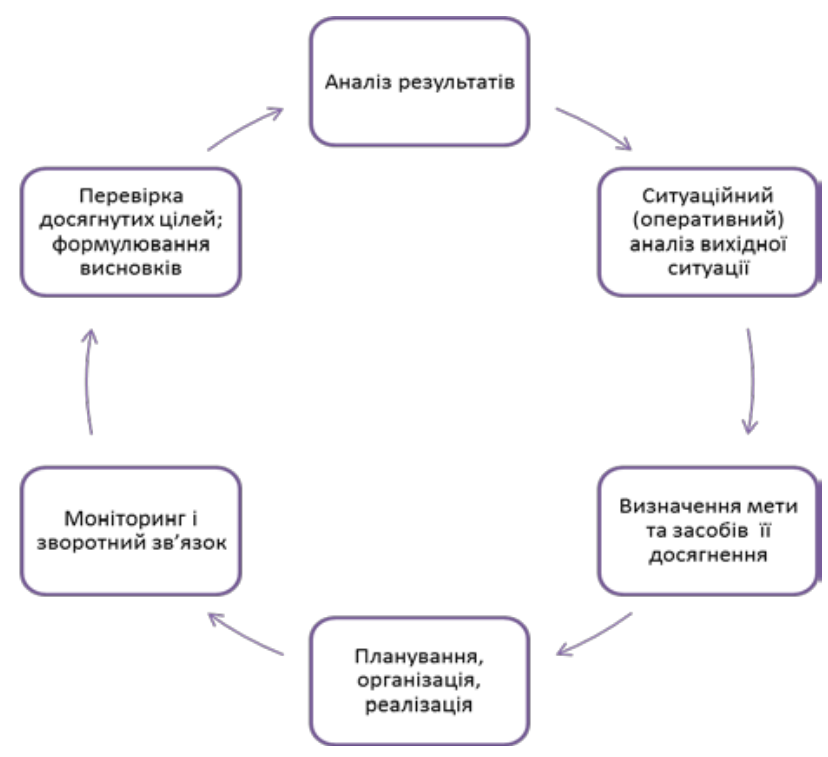

Рис. 1. Цикл менеджменту якості Університету м. Грац (Entwicklungsplan 2019-2024:

Die Karl-Franzens-Universität Graz, 2019)
- система менеджменту якості спрямована також на створення умов для здійснення прогресивних наукових досліджень. Їхня всебічна підтримка сприяє забезпеченню якості навчального процесу й підвищенню конкурентоспроможності університету на внутрішньому й міжнародному ринку освітніх послуг;

- так само зростає значення підвищення якості професійного розвитку кадрів, а також функціонування університетської інфраструктури. Усі вони $\epsilon$ стратегічними пріоритетами університету; ї відповідний рівень якості повинен досягатися 3 максимальною ефективністю.

Щодо концепції забезпечення якості, то університет орієнтується на цикл менеджменту якості (див. рис. 1).

Він починається 3 аналізу вихідної ситуації, далі здійснюється встановлення обраних цілей. Наступним етапом буде визначення відповідних заходів для досягнення мети, їхня реалізація та систематичне спостереження, надалі - перевірка й оцінка результатів, відповідні висновки й перевірка впливу.

Для всіх елементів циклу визначаються відповідні заходи й інструменти впливу, вони $є$ послідовними й взаємопов'язаними видами діяльності.

Аналізуючи представлену концептуальну модель менеджменту якості, можна зробити висновок про їх базування на циклі Демінга (англ. - Deming Cycle, «коло якості»), що знаходить застосування в галузі виробничого менеджменту. Він становить стале коло регулювання вдосконалення продукту й виробничих процесів, оптимізації окремих одиниць та об'єктів.

Названу модель часто називають циклом PDCA (англ. - Plan-Do-Check-Act): планування - здійснення - перевірка - впровадження результатів. За допомогою постійних перевірок до, під час i після процесу виробництва можуть бути виявлені слабкі місця в різноманітних процесах на виробничому підприємстві. Цикл PDCA служить передусім для виявлення причин браку й підтримки всього процесу аж до усунення дефектів.

Що стосується електронного навчання, то Університет ім. Карла Франца м. Грац декларує повну відповідність очікуванням студентів «щодо сучасних та якісних освітніх сценаріїв». Така мета досягається за допомогою широкого спектра програм електронного навчання та застосування відповідних інформаційно-комунікаційних технологій для його підтримки. Викладачам пропонуються індивідуальні поради й тренінги щодо дидактичних i технічних аспектів використання інформаційно-комунікаційних технологій електронного 
(дистанційного) навчання та різноманітних мультимедійних засобів із метою передачі й запису курсів, відеоконференцій, проведення онлайнопитувань тощо (Entwicklungsplan 2019-2024: Die Karl-Franzens-Universität Graz, 2019).

Для того, щоб створювати й впроваджувати електронні навчальні курси, систематично їх удосконалювати й краще розуміти відповідну систему якості освіти, Центр електронного навчання Дунайського університету м. Кремс регулярно вдосконалює відповідні навички викладачів, розробляючи проєкти 3 використанням інформаційно-комунікаційних технологій як засобу оптимального поєднання наукової, навчальної, виховної, практичної діяльності викладача й студента. Так, у ході проєкту eLQE (eLearning QualitätsEvaluationstool) розробляються інструменти для оцінки процесу, програми, змісту й реалізації заходів університетського електронного навчання. Особлива увага приділяється інструментам оцінки, критеріям і показникам, які надають можливість відбивати й кількісно оцінювати якість навчальних курсів. Проєкт підтримує керівників програм і викладачів у плануванні й проведенні заходів електронного навчання (Entwicklungsplan der Universität für Weiterbildung Krems (DonauUniversität Krems), 2019).

Висновки. Загалом, аналізуючи всі наведені вище особливості стратегічного планування у сфері забезпечення якості австрійських університетів, можемо зробити висновок про його особливий характер, гнучкість, багатоаспектність і спрямованість на підвищення конкурентоздатності освітніх послуг на внутрішньому й міжнародному ринку. У контексті пріоритетів Болонського процесу щодо забезпечення якості університетської освіти рівнозначні зусилля зосереджуються також і на електронному навчанні, адже сучасна європейська молодь обирає навчальний заклад, конкурентоспроможний на ринку освітніх послуг. Австрійські університети забезпечують якість освіти шляхом творчого застосування сучасних інформаційно-комунікаційних і педагогічних технологій, удосконалення системи розвитку творчого потенціалу майбутніх фахівців для їхньої професійної самореалізації.

\section{СПИСОК ВИКОРИСТАНИХ ДЖЕРЕЛ}

1. Князев Е. А. Об университетах и их стратегиях. 2005. URL: http://ecsocman.hse.ru/data/618/086/1217/9-17.pdf.

2. Кронівець Т. М. Електронна освіта у вищих навчальних закладах України: проблеми і перспективи правового регулювання. Науковий часопис Національного педагогічного університету ім. М. П. Драгоманова. Київ : Видавництво НПУ ім. Драгоманова, 2013. Вип. 22. С. 134-140.

3. Педагогічні аспекти відкритого дистанційного навчання : монографія / під ред. О. О. Андрєєва, В. М. Кухаренко. Харків : Міськдрук, 2013. 212 с.

4. Euler Dieter, Seufert Sabine. Nachhaltigkeit von eLearningInnovationen: Fallstudien zu Implementierungsstrategien von eLearning als Innovationen an Hochschulen. 2005. URL: https://www.e-teaching.org/projekt/fallstudien/2005-01seufert-euler-nachhaltigkeit-elearning.pdf.

5. Entwicklungsplan 2019-2024: Die Karl-Franzens-Universität Graz. 2019. URL: https://static.uni-graz.at/fileadmin/ Lqm/Dokumente/Entwicklungsplan_2019-2024.pdf.

6. Entwicklungsplan der Universität für Weiterbildung Krems (Donau-Universität Krems) 2019 bis 2024. URL: https://www.donau-uni.ac.at/dam/jcr:15c0dec4-2c0e-4f27-8298-7cbef1f387dd/entwicklungsplan_donau-universitaet_ krems_2019-2024.pdf;jsessionid=F044013AC0873F4C3A3B76A975812B37.

\section{REFERENCES}

1. Knyazev Ye (2005). Ob universitetakh i ikh strategiyakh. [About universities and their strategies]. 2005. URL: http://ecsocman.hse.ru/data/618/086/1217/9-17.pdf. [in Russian].

2. Kronivets' T. Elektronna osvita u vyshchykh navchal'nykh zakladakh Ukrayiny: problemy i perspektyvy pravovoho rehulyuvannya. [Electronic education in higher educational institutions of Ukraine: problems and prospects of legal regulation]. Scientific Journal of National Pedagogical Dragomanov University. Series 18. Economics and law, 2013 Issue 22, pp. 134-140 [in Ukrainian].

3. Pedahohichni aspekty vidkrytoho dystantsiynoho navchannya : monohrafiya. [Pedagogical aspects of open distance learning: monograph]. pid red. O. O. Andryeyeva, V. M. Kukharenko. Kharkiv : Mis'kdruk, 2013. 212 s. [in Ukrainian].

4. Euler Dieter, Seufert, Sabine. Nachhaltigkeit von eLearningInnovationen: Fallstudien zu Implementierungsstrategien von eLearning als Innovationen an Hochschulen. 2005. URL : https://www.e-teaching.org/projekt/fallstudien/2005-01-seufert-euler-nachhaltigkeit-elearning.pdf.

5. Entwicklungsplan 2019-2024: Die Karl-Franzens-Universität Graz. 2019. URL : https://static.uni-graz.at/fileadmin/ Lqm/Dokumente/Entwicklungsplan_2019-2024.pdf.

6. Entwicklungsplan der Universität für Weiterbildung Krems (Donau-Universität Krems) 2019 bis 2024. URL.: https://www.donau-uni.ac.at/dam/jcr:15c0dec4-2c0e-4f27-8298-7cbef1f387dd/entwicklungsplan_donau-universitaet_ krems_2019-024.pdf;jsessionid=F044013AC0873F4C3A3B76A975812B37. 